\title{
Variations in the abundance of three Parulidae species in the southern portion of the Brazilian Atlantic Forest, state of Paraná
}

\author{
CÁSSIUS R. SANTANA ${ }^{1}$, GABRIELA M. BOCHIO ${ }^{1}$ and LUIZ DOS ANJOS ${ }^{2}$ \\ ${ }^{1}$ Programa de Pós-Graduação em Ciências Biológicas, Departamento de Biologia Animal e Vegetal (BAV), \\ Universidade Estadual de Londrina, Caixa Postal 6001, 86051-990 Londrina, PR, Brasil \\ ${ }^{2}$ Departamento de Biologia Animal e Vegetal, Universidade Estadual de Londrina, \\ Caixa Postal 6001, 86051-970 Londrina, PR, Brasil
}

Manuscript received on June 2, 2010; accepted for publication on January 1, 2011

\begin{abstract}
We evaluated the distribution of abundance of three species of warblers in the southern portion of the Brazilian Atlantic Forest (BAF): Tropical Parula (Parula pitiayumi), the Golden-Crowned Warbler (Basileuterus culicivorus) and the White-Rimmed Warbler (Basileuterus leucoblepharus). Three types of forests comprise this region of the Atlantic Forest: seasonal semi-deciduous forest (SF), mixed rain forest (MF) and dense rain forest (DF). These forest types occur at different elevations: SF ranging from 200 to $800 \mathrm{~m}, \mathrm{MF}$ ranging from 800 to $1,200 \mathrm{~m}$ and $\mathrm{DF}$ ranging from sea level up to 2,000 $\mathrm{m}$. We used point counts in fifteen study areas distributed in the three forest types. The White-Rimmed Warbler and the Tropical Parula had higher abundances in MF, and their abundance was positively correlated with the elevation. The Golden-Crowned Warbler did not present a significant difference in abundance among the forest types, and no correlation between abundance and elevation was found. We suggest that the difference in the occupancy of the forest strata by the Golden-Crowned Warbler is because this species is more generalist and thus less sensitive to variations in the vegetation structure among the forests types when compared to the other two warbler species.
\end{abstract}

Key words: abundance, Atlantic Forest, Basileuterus, distribution, elevation, warblers.

\section{INTRODUCTION}

Studies on variations in bird distribution and abundance along elevational and latitudinal gradients are common in the ornithological literature (e.g. Terborgh 1971, 1977). Regarding the family Parulidae, we can find studies on the effects of elevation on the population distribution in North and Central America (Kepler and Parkes 1972,

Correspondence to: Cássius Ricardo Santana

E-mail: cassius.santana@gmail.com
Morse 1979, Hutto 1985). Lanning et al. (1990) studied the distribution of the Colima Warbler (Vermivora crissalis) and observed variations in population size and habitat occupancy of another three Parulidae species in an elevational gradient between 1,700 and 3,000 $\mathrm{m}$ at the border between Mexico and the United States. Blake and Loiselle (2000) reported higher numbers of warbler species at lower elevations between 50 and $1,000 \mathrm{~m}$ in the central coast of Costa Rica. 
In South America there are about 60 Parulidae species. These birds, known as warblers, can be divided into two groups (Ridgely and Tudor 1989): migrants (in North America) and residents, which are mostly Basileuterus. Little is known about the distribution of these species along elevational gradients in Brazil, although Ridgely and Tudor (1989) mention general trends in their occupation. According to these authors, the WhiteRimmed Warbler and the Tropical Parula occur in mountainous areas, up to $1,600 \mathrm{~m}$ and $2,500 \mathrm{~m}$, respectively. The Golden-Crowned Warbler presents a wide elevational distribution up to 1800 m (Ridgely and Tudor 1989).

In this study we analyzed the distribution of abundance of these three Parulidae species in three different forest ecosystems in the southern Brazilian Atlantic Forest (BAF), which occupy different elevations: mixed rain forest (MF), dense rain forest (DF) and seasonal semi-deciduous forest (SF). Variations in the abundance of these species according to elevation are expected, although they tend to co-exist in the three forest types.

\section{STUDY AREA}

This study was conducted in areas of continuous forest of the BAF in the state of Paraná, southern Brazil, covering the three forest types: MF, DF and SF. Fifteen areas were sampled. Three of these areas represent some of the larger continuous portions within their respective forest types in the Paraná state: Parque Nacional do Iguaçu $(185,000$ ha) in the SF, Floresta Nacional de Irati (3,500 ha) in the MF and Área de Preservação Ambiental de Guaraqueçaba (192,000 ha) in the DF. Four areas are smaller (between 656 and 1,000 ha), but also legally protected. Another five areas are not protected, but are also as well preserved as the Conservation Units (Table I). The three forest types studied differ in biotic and abiotic characteristics. In the DF, where our study areas were distributed from sea level up to
$800 \mathrm{~m}$ (although this forest type can reach 2,000 m), annual rainfall and average temperatures are high. There is no obvious dry season and the rainfall is well distributed throughout the year. The complex canopy is composed of a great variety of plant species (around 700 species of trees are found), displaying an abundance of epiphytes and large biomass of bamboo and vine tangles (Morellato and Haddad 2000, Oliveira-Filho and Fontes 2000).

The MF, which occupies elevations ranging from 800 to $1,200 \mathrm{~m}$, is dominated by a single plant species: Araucaria angustifolia, which represents more than $40 \%$ of the individual trees. This type of forest is poor in bamboo and vine tangles, but rich in epiphytes. The annual average temperatures and rainfall are lower than those found in the DF, and there is no distinct dry season (Mazza et al. 2005). The SF, ranging from 200 to $800 \mathrm{~m}$ in elevation, is dominated by a few plant species, of which Aspidosperma polyneuron, Tabebuia heptaphylla and Peltophorum dubium are noteworthy. This type of forest is rich in vine tangles and bamboo, but poor in epiphytes. The average annual rainfall is similar to that observed in the MF; however, the average temperature is similar to that in the DF. A distinct dry season of 160 days can be observed in this type of forest (Morellato and Haddad 2000, Oliveira-Filho and Fontes 2000).

BIRD SAMPLING METHODS

Point counts were performed to obtain the abundance data in all study areas (Blondel et al. 1970, Vielliard and Silva 1990, Bibby et al. 1992 , Anjos 2007). This method was applied establishing six points along a trail at a distance of $200 \mathrm{~m}$ of each other. Another six points were set along another trail located at least $300 \mathrm{~m}$ from the first one (replicate). Thus, each sampling site considered in this study was represented by 12 sampling points distributed in two trails. The samplings on each site were conducted on consecutive days. More than one site 
was sampled in larger areas such as Parque Nacional do Iguaçu (where four trails of six points were sampled). The sampling occurred seasonally over a two year period, totaling 16 sampling days in almost all studied areas, or 96 sampling points at each site.

Samplings at each point were conducted in the morning, starting with the early bird activity in the day. The points were sampled in sequence, inverting the starting point at each season. Each point count was surveyed for fifteen minutes, which was also the interval between the sampling points. Thus, the sampling on each track ended 2 h 45 min after the first point. Visual and/or auditive records were considered within an estimated radius of $100 \mathrm{~m}$, and each breeding pair or group was considered as one contact. A standard schematic form allowed the observer to avoid repeating records of an individual at the same point.

\section{DATA ANALYSIS}

To determine the abundance of each species at each sampling site the Ponctual Index of Abundance (IPA) was obtained (Blondel et al. 1970, Bibby et al. 1992, Anjos 2007). This index was calculated for each species by dividing its number of contacts by the total number of points sampled in each site (Blondel et al. 1970). A non-parametric Kruskal-Wallis (H) test was applied to evaluate differences between the median values of the species' I.P.A. for the different forest types. The correlation significance between the values of I.P.A. and the elevation of the sampling sites for each species was evaluated using a Spearman Rank Correlation test (rs).

\section{RESULTS AND DISCUSSION}

All three species occurred in the three forest types. However, only the Golden-Crowned Warbler occurred in all sampling sites (Table I). The White-Rimmed Warbler and the Tropical Parula presented significantly higher I.P.A. medians in the MF (Kruskall-Wallis, $H=10.3, \mathrm{P}<0.01$ and
$H=11.4, \mathrm{P}<0.01$, respectively). Regarding the Golden-Crowned Warbler there was no difference in median values of I.P.A. among the forest types (Kruskall-Wallis, $H=3.2, \mathrm{P}=0.20$ ).

The White-Rimmed Warbler and the Tropical Parula showed significant positive correlations between abundance and altitude $\left(\mathrm{r}_{\mathrm{s}}=0.70, \mathrm{P}<0.01\right.$ and $\mathrm{r}_{\mathrm{s}}=0.73, \mathrm{P}<0.01$, respectively) (Fig. 1). No correlation was found for the Golden-Crowned Warbler ( $\left.\mathrm{r}_{\mathrm{s}}=-0.12, \mathrm{P}=0.65\right)$ (Fig. 1).

The data obtained suggest that elevation affects the abundance of the White-Rimmed Warbler and the Tropical Parula in the southern portion of the Atlantic Forest; both presented greater abundance at higher elevations. This result proves to be similar to that found for several warbler species of temperate Northern Hemisphere forests such as the Painted Redstart (Myioborus pictus), the Oliver Warbler (Peucedramus taeniatus), the YellowRumped Warbler (Dendroica coronate), the Colima Warbler (Vermivora crissalis) and the CrescentChested Warbler (Vermivora superciliosa, now in the genus Parula), which increased in occurrence with the increasing elevation (Hubbard and Crossin 1974 , Morse 1979, Lanning et al. 1990). The data obtained for the southern portion of the Atlantic Forest show a more similar pattern to temperate regions than to tropical zones considering the study of Blake and Loiselle (2000) in Costa Rica, where the abundance of Parulidae was higher at lower elevations ranging from $50 \mathrm{~m}$ to $1,000 \mathrm{~m}$.

However, it is noticeable that the Atlantic Forest is not homogeneous, and these species are actually more related to the MF, which occurs at higher elevations and latitudes. Thus, although the geographic distribution of these species comprises large portions of the Atlantic Forest in the southern and southeastern Brazil (Ridgely and Tudor 1989), biotic and abiotic characteristics of the forest types influence variations in their abundance (Anjos 2002).

Variations in abundance were not detected for the Golden-Crowned Warbler, suggesting a higher 
TABLE I

Values of the Ponctual Index of Abundance (IPA), followed by respective means \pm standart deviations for the Golden-Crowned Warbler (G-C. warbler), the White-Rimmed Warbler (W-R. warbler) and the Tropical Parula (T. Parula) at each of the sites located in the three types of forest: seasonal semi-deciduous forest (FS), mixed rain Forest (MF) and dense rain forest (DF).

\begin{tabular}{|c|c|c|c|c|}
\hline \multirow{2}{*}{ Sites } & \multirow{2}{*}{ Elevation (m) } & \multicolumn{3}{|c|}{ Species } \\
\hline & & G-C. Warbler & W-R. Warbler & T. Parula \\
\hline \multicolumn{5}{|l|}{ FS } \\
\hline $\begin{array}{l}\text { Fazenda Solana } \\
\left(23^{\circ} 24^{\prime} 25^{\prime \prime} \mathrm{S}, 51^{\circ} 21^{\prime} 56^{\prime \prime} \mathrm{W}\right)\end{array}$ & 690 & 1.55 & 0.26 & 0,2 \\
\hline $\begin{array}{l}\text { Parque Estadual Mata dos Godoy } \\
\left(23^{\circ} 27^{\prime} 08^{\prime \prime} \mathrm{S}, 51^{\circ} 15^{\prime} 08^{\prime \prime} \mathrm{W}\right)\end{array}$ & 650 & 1.18 & 0.02 & 0 \\
\hline $\begin{array}{l}\text { Parque Nacional do Iguaçu - Floriano } \\
\left(25^{\circ} 36^{\prime} 05^{\prime} \mathrm{S}, 54^{\circ} 25^{\prime} 47^{\prime \prime} \mathrm{W}\right)\end{array}$ & 635 & 0.46 & 1.13 & 0.09 \\
\hline $\begin{array}{l}\text { Fazenda Colorado } \\
\left(23^{\circ} 28^{\prime} 13^{\prime \prime} \mathrm{S}, 51^{\circ} 022^{\prime} 85^{\prime \prime} \mathrm{W}\right)\end{array}$ & 520 & 1.19 & 0.03 & 0.12 \\
\hline \multirow[t]{2}{*}{$\begin{array}{l}\text { Parque Nacional do Iguaçu - Iguaçu } \\
\left(25^{\circ} 36^{\prime} 52^{\prime \prime} \mathrm{S}, 54^{\circ} 25^{\prime} 14^{\prime \prime} \mathrm{W}\right)\end{array}$} & 220 & 0.97 & 0.07 & 0.32 \\
\hline & & $1.1 \pm 0.4$ & $0.3 \pm 0.4$ & $0.15 \pm 0.12$ \\
\hline \multicolumn{5}{|l|}{ MF } \\
\hline $\begin{array}{l}\text { Corvo Branco } \\
\left(28^{\circ} 02^{\prime} 30^{\prime \prime} \mathrm{S}, 49^{\circ} 23^{\prime} 90^{\prime \prime} \mathrm{W}\right)\end{array}$ & 1080 & 0.69 & 1.28 & 0.74 \\
\hline $\begin{array}{l}\text { São José } \\
\left(28^{\circ} 011^{\prime} 10^{\prime \prime} \mathrm{S}, 49^{\circ} 27^{\prime} 33^{\prime \prime} \mathrm{W}\right)\end{array}$ & 1035 & 0.51 & 1.34 & 0.77 \\
\hline $\begin{array}{l}\text { Panelão } \\
\left(27^{\circ} 53^{\prime} 16^{\prime \prime} \mathrm{S}, 49^{\circ} 35^{\prime} 58^{\prime \prime} \mathrm{W}\right)\end{array}$ & 1030 & 0.25 & 1.38 & 0.69 \\
\hline $\begin{array}{l}\text { Floresta Nacional de Irati - FLONA } \\
\left(25^{\circ} 24^{\prime} 03^{\prime \prime} \mathrm{S}, 50^{\circ} 35^{\prime} 11^{\prime \prime} \mathrm{W}\right)\end{array}$ & 940 & 0.73 & 1.6 & 0.48 \\
\hline $\begin{array}{l}\text { RPPN Tarumã } \\
\left(25^{\circ} 18 ’ 12^{\prime} \text { S, } 49^{\circ} 48^{\prime} 53^{\prime}, \mathrm{W}\right)\end{array}$ & 900 & 1.18 & 1.72 & 0.53 \\
\hline \multirow[t]{2}{*}{$\begin{array}{l}\text { Parque Ecológico da Klabin } \\
\left(24^{\circ} 21^{\prime} 022^{\prime} \mathrm{S}, 50^{\circ} 34^{\prime} 11^{\prime \prime} \mathrm{W}\right)\end{array}$} & 815 & 1.12 & 2.01 & 0.72 \\
\hline & & $0.7 \pm 0.3$ & $1.5 \pm 0.3$ & $0.6 \pm 0.1$ \\
\hline \multicolumn{5}{|l|}{ DF } \\
\hline $\begin{array}{l}\text { Mananciais } \\
\left(25^{\circ} 26^{\prime} 32^{\prime} ' \mathrm{~S}, 48^{\circ} 58^{\prime} 59^{\prime} ’ \mathrm{~W}\right)\end{array}$ & 1070 & 0.62 & 0.75 & 0.02 \\
\hline $\begin{array}{l}\text { APA Guaraqueçaba I } \\
\left(25^{\circ} 14^{\prime} 41^{\prime \prime} \mathrm{S}, 48^{\circ} 40^{\prime} 55^{\prime \prime} \mathrm{W}\right)\end{array}$ & 200 & 0.53 & 0 & 0 \\
\hline $\begin{array}{l}\text { APA Guaraqueçaba II } \\
\left(25^{\circ} 18^{\prime} 21^{\prime \prime S}, 48^{\circ} 40^{\prime} 32^{\prime \prime} \mathrm{W}\right)\end{array}$ & 100 & 0.65 & 0 & 0 \\
\hline \multirow[t]{2}{*}{$\begin{array}{l}\text { APA Guaraqueçaba III } \\
\left(25^{\circ} 24^{\prime} 144^{\prime} \mathrm{S}, 48^{\circ} 40^{\prime} 34^{\prime \prime} \mathrm{W}\right)\end{array}$} & 50 & 0.62 & 0.12 & 0 \\
\hline & & $0.6 \pm 0.1$ & $0.2 \pm 0.3$ & $0.01 \pm 0.0001$ \\
\hline
\end{tabular}




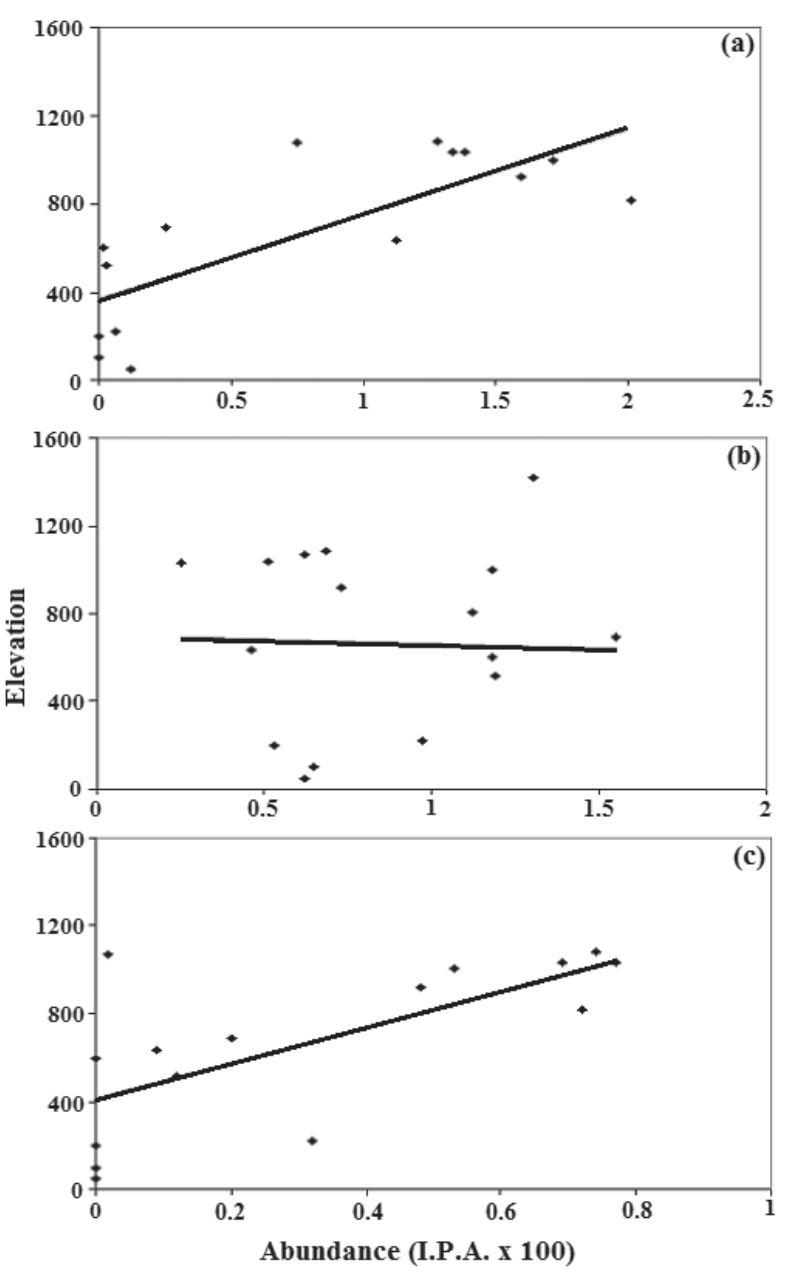

Fig. 1 - Correlation between IPA values and elevation for the three Parulidae species studied: (a) Basileuterus leucoblepharus ( $\mathrm{rs}=0.70$, $\mathrm{P}<0.01$ ), (b) B. culicivorus ( $\mathrm{rs}=-0.12, \mathrm{P}=0.65$ ) and (c) Parula pitiayumi $(\mathrm{rs}=0.73, \mathrm{P}<0.01)$.

tolerance of this species to spatial variations of the environment. The reasons why the Golden-Crowned Warbler was more tolerant to variations along the BAF than the other two species are not clear. The explanation may lie in the occupation of the forest strata (Ridgely and Tudor 1989): the WhiteRimmed Warbler is commonly found in dense undergrowth of rainforests, the Tropical Parula preferentially occupies the canopy of trees in the upper strata, and the Golden-Crowned Warbler is often observed in mixed flocks present in the middle and lower strata. Considering that the three species are predominantly insectivorous, the fact that the
White-rimmed Warbler and the Tropical Parula are more restricted to specific strata of the forest (lower and higher, respectively) could possibly reduce their ability to seek prey in different forest types where the vegetation structure presents more variations. The Golden-Crowned Warbler, which forages in the forest middle stratum, could be more generalist than the other two species in relation to the occupancy of the arboreal strata (MendonçaLima et al. 2004, Chatellenaz 2008), and therefore less sensitive to changes in the vegetation structure.

\section{ACKNOWLEDGMENTS}

Financial support for this study was obtained from Conselho Nacional de Desenvolvimento Científico e Tecnológico $(\mathrm{CNPq})$ through the Mata Atlântica Program, and from Fundação Araucária (Curitiba). Research grants for the authors from $\mathrm{CNPq}$ (133549/07-0; 305593/07-2 and 201476/07-0) and from Fundação Araucária were received during the period. We thank the Instituto Ambiental do Paraná (36/07, 51/07; Curitiba) for permissions to conduct research in the Reserves, and the owners of private lands where some sites are located. We also thank K. Cockle for the valuable suggestions. F. L. Fávaro and E. V. Lopes helped during the field work.

\section{RESUMO}

Nós avaliamos as distribuições de abundância em três espécies de parulídeos na porção sul da Mata Atlântica do Brasil: a Mariquita (Parula pitiayumi), o Pula-pula (Basileuterus culicivorus) e o Pula-pula-assobiador (Basileuterus leucoblepharus). Três diferentes tipos de formações florestais compõem esta região da Mata Atlântica: a floresta estacional semidecidual (FES), a floresta ombrófila mista (FOM) e a floresta ombrófila densa (FOD). Estes tipos de floresta ocupam altitudes diferentes: FES ocorre entre $200 \mathrm{~m}$ e 800 m, a FOM é encontrada entre $800 \mathrm{~m}$ e $1200 \mathrm{~m}$ de altitude e a FOD ocorre desde o nível do mar até 2000 m. Nós usamos 
pontos de escuta em 15 áreas florestais localizadas nos três tipos de floresta. O Pula-pula-assobiador e a Mariquita apresentaram maior abundância na FOM e uma correlação positiva entre abundância e altitude. Já o Pula-pula não apresentou diferença significativa de abundância entre os três tipos floresta nem correlação entre abundância e altitude. Nós sugerimos que a diferença de ocupação dos estratos de floresta por Pula-pula é resultante do fato desta espécie ser mais generalista e, portanto, menos sensível a variações na estrutura de vegetação entre os tipos de floresta quando comparada às duas outras espécies de parulídeos.

Palavras-chave: abundância, Mata Atlântica, Basileuterus, distribuição, altitude, parulídeos.

\section{REFERENCES}

ANJos L. 2002. Forest Bird Communities in the Tibagi river hydrographic basin, southern Brazil. Ecotropica 8: 67-79.

ANJos L. 2007. A eficiência do método de amostragem por pontos de escuta na avaliação da riqueza de aves. Rev Bras Orn 15: 239-243.

BibBy C, Burguess ND AND Hill DA. 1992. Bird Census Techniques. British Trust for Ornithology and the Royal Society for the Protection of Birds. London: Academic Press.

BLAKE JG AND LOISELLE BA. 2000. Diversity of birds along an elevational gradient in the cordillera central, Costa Rica. Auk 117: 663-686.

BlONDEL J, FERRY C AND FrochOT B. 1970. La méthode des indices ponctuels d'abundance (IPA) ou des releves d'avifaune par "stations d'écoute". Alauda 38: 55-71.

CHATELlenAZ ML. 2008. Ecología alimentaria de dos especies simpátricas del género Basileuterus en el Noreste de Argentina. Hornero 23: 87-93.

HubBARD JP AND CROSSIN RS. 1974. Notes on northern Mexican birds. Nemouria, Occas. Pap. Delaware Mus Nat Hist 14: 1-41.
HuTTO RL. 1985. Seasonal changes in the habitat distribution of transient insectivorus birds in southeastern Arizona: competition mediated? Auk 102: 120-132.

KePler CB AND PARKes K. 1972. A new species of warbler (Parulidae) from Puerto Rico. Auk 89: 1-18.

LANNING D, MARShall JT AND SHIFLETT JT. 1990. Range and habitat of Colima Warbler. Wilson Bull 120: 1-13.

Mazza CAS, SANTOS JE, Mazza MCM, MatTos PP AND RACHWAL MFG. 2005. Caracterização ambiental dos componentes estruturais da paisagem do município de Irati, Paraná. Bol Pesq Des Embrapa Florestas Colombo 25: 1-45.

MendonÇA-Lima A, Hartz SM AND Kindel A. 2004. Foraging behavior of the White-Browed (Basileuterus leuco-blepharus) and the Golden-Crowned (B. culicivorus) warblers in a semidecidual forest in Southern Brazil. Ornitol Neotrop 15: 5-15.

MoRELlATO LPC AND HADDAD CFB. 2000. Introduction: The Brazilian Atlantic forest. Biotropica 32: 786-792.

MoRSE DH. 1979. Habitat use by the Blackpoll warbler. Wilson Bull 91: 234-243.

OliveIRA-FILHO AT AND FonTES MAL. 2000. Patterns of floristic differentiation among Atlantic forests in southeastern Brazil, and the influence of climate. Biotropica 32: 793-810

RIDGELY RS AND TUdOR G. 1989. The Birds of South America Vol. 1: The oscine passerines. The United States: Oxford University Express, 516 p.

TERBORGH J. 1971. Distribution on environmental gradients: theory and a preliminary interpretation of distribution patterns in the avifauna of cordillera Vilcabamba, Peru. Ecology 52: 23-40.

Terborgh J. 1977. Birds species diversity on an Andean elevation gradient. Ecology 58: 1007-1019.

VIELLIARD JEM AND SILVA WR. 1990. Nova metodologia de levantamento quantitativo da avifauna e primeiros resultados no interior do Estado de São Paulo, Brasil. In: IV ENCONTRO NACIONAL DE ANILHADORES DE AVES. Recife. Universidade Federal de Pernambuco PE, Brasil, p. 117-151. 